\title{
FENOMENA PERGESERAN BUDAYA DENGAN TREND PERNIKAHAN DINI DI KABUPATEN SLEMAN D.I. YOGYAKARTA
}

\author{
CULTURE SHIELD PHENOMENON WITH EARLY WEDDING TREND IN \\ SLEMAN DISTRICT D.I. YOGYAKARTA \\ $\underline{\text { Yekti Satriyandari }}^{1}$, Fitria Siswi Utami ${ }^{2}$ \\ ${ }^{1,2}$ Program Studi Kebidanan Program Sarjana Terapan Universitas ‘Aisyiyah \\ Yogyakarta Indonesia \\ Email : yekti_1998@yahoo.co.id, fitriastikes@gmail.com
}

\begin{abstract}
ABSTRAK
Pernikahan merupakan ikatan suci yang menyatukan antara laki-laki dan perempuan. Yogyakarta memiliki angka yang tinggi kasus pernikahan dini. Adanya pergeseran budaya menjadi salah satu penyebabnya. Tujuan penelitian ini adalah untuk mengetahui fenomena pergeseran budaya dengan trend pernikahan dini. Penelitian ini menggunakan metode kualitatif. Pendekatan waktu cross sectional. Pengambilan data indepht interview. Teknik pengambilan sampel purposive sampling.Populasi adalah seluruh pasangan usia subur yang ada di Kecamatan Godean yang menikah dini usia kurang dari 16 tahun untuk perempuan dan kurang dari 19 untuk laki-laki. Subyek penelitian ini Tenaga kesehatan 1, Petugas KUA 1, Tokoh Masyrakat 1, Orangtua yang memiliki anak menikah dini 5, dan pasangan yang menikah dini 5. Faktor remaja melakukan pernikahan dini di Kecamatan Godean karena kehamilan tidak diinginkan dan saat ini fenomena pernikahan dini karena kehamilan tidak diinginkan bukan menjadi hal tabu lagi di masyarakat meskipun itu adalah aib yang seharusnya di tutupi namun karena mengalami pergeseran budaya hal tersebut sudah menjadi fenomena biasa yang ada di masyarakat. Pasangan yang menikah dini kurang memiliki kesiapan fisik, sosial, psikologis dan spiritual. Pasangan yang menikah dini tidak dapat melanjutkan pendidikan sehingga sulit mendapatkan pekerjaan yang menimbulkan masalah keuangan dalam rumah tangga. Dampak lain kurangnya keharmonisan dalam keluarga. Dalam mengatasi hal tersebut Puskesmas dan KUA mengadakan program khusus bagi calon penganten yaitu pembinaan pra nikah dan adanya kerjasama lintas sektoral.
\end{abstract}

Kata kunci : Fenomena, Budaya, Trend, Pernikahan Dini

\begin{abstract}
Marriage is the legally or formally recognized union between a man and a woman as partner in a personal relationship. Yogyakarta Province has a high number of early marriage cases. The study was conducted to explain the phenomenon of culture friction on trend of early marriage. A qualitative method with cross sectional approach was used in this study. 13 informan including 1 public figure, 1 health care provider, 1 staff of religious affairs office, 5 parents who had early marriage children, and 5 early marriage couples were recruited using purposive sampling technique. An indepth interview methode was used to collect the data from all informans. The result of this study explains that the reason to early marrige is unwanted pregnancy. Moreover, early marriage because of unwanted pregnancy is not a weird case anymore among the society although unwanted pregnancy is ignominy case which is have to covered up. It was an explaination of the culture friction on early marriage phenomenon. Early marriage couples do not have readiness on physical, social, psychological, and spiritual in order to deal with the new family life. Early marriage couples can not continue their study with the result that thay can not reach a job with adequate income. As a result, economical problem is one of promblem which is
\end{abstract}


come to their family life. Early marriage also can impact to the lack of harmonius family life. It is recommended to Primary Health Center and Religious Affairs Office to develop an integrated premarriage course to early marriage couples combining with inter sectoral collaboration program.

Keywords: culture, early marriage, phenomenon, trend

\section{PENDAHULUAN}

Saat ini remaja dihadapkan pada problematika banyaknya remaja yang ingin membina rumah tangga dengan melakukan pernikahan dini.Menurut Undang-undang perkawinan No.1 tahun 1974 pasal 7 ayat (1), batasan usia menikah bagi perempuan adalah 16 tahun dan pada laki-laki adalah 19 tahun. Upaya menangani masalah tersebut dengan usulan pendewasaan usia perkawinannamun sampai saat ini belum membuahkan hasil. Di sisi lain, pemberian dispensasi bagi pasangan dibawah umur menjadi peluang untuk melakukan pernikahan dini.

Permasalahan pernikahan usia dini saat ini sudah menjadi permasalahan dunia. Data UNICEF menunjukkan lebih dari 700 juta perempuan menikah saat usia anak-anak bahkan 1 dari 3 diantara perempuan yang menikah usia dini menikah pada usia sebelum 15 tahun (UNICEF, 2016). Data BKKBN 2014 menujukkan bahwa jumlah remaja di Indonesia sudah mencapai 74 juta jiwa dari jumlah tersebut 59\% berusia 15- 19 tahun sudah menikah (Guilbert, 2013). Pernikahan dini di Indonesia menduduki peringkat ke 37 di Dunia pada tahun 2010, hal ini berarti Indonesia termasuk negara dengan presentase pernikahan dini tinggi di Dunia. Data SDKI (2012) menyebutkan bahwa 340 ribu anak perempuan menikah pada usia dini setiap tahunnya.

Pernikahan dini di beberapa Negara dianggap sebagai alternatif penyelesaian masalah kemiskinan keluarga. Keluarga miskin dianggap dapat terbantu saat anak perempuan mereka menikah dini sehingga dapatmembantu mengurangi beban ekonomi keluarga.Purnomo (2013) menyebutkan selain alasan ekonomi, pernikahan dini banyak dilakukan dengan alasan sudah terlalu dekatnya hubungan anak perempuan dengan teman laki-lakinya, sudah pernah melakukan hubungan seksual, terjadinya kehamilan pranikah, kekhawatiran sebagai perawan tua, serta kemudahan media dalam mengakses konten-konten seksualitas.

Fenomena tersebut terjadi di Indonesia, khususnya di Propinsi D.I. Yogyakarta. Data Pernikahan di bawah umur, dari Kementrian Agama Daerah Istimewa Yogyakarta, tahun 2015 sebanyak 252. Dengan persentase tertinggi kabupaten Sleman (38,9\%) atau 98 orang, kota Yogyakarta (5,2\%) sebesar 13 orang, kabupaten Kulon Progo (13,5\%) sebesar 34 orang, Kabupaten Gunung Kidul $(19,4 \%)$ sebesar 49 orang dan kabupaten Bantul (23\%) sebesar 58 orang dan ditahun 2016 prosentase kejadian pernikahan dini di Sleman tertinggi di Kecamatan Godean.

Maraknya perkawinan di bawah umur dapat dilihat pada permohonan despensasi nikah karena calon pengantin perempuan hamil sebelum menikah. 
Bahkan data BPS menyebutkan bahwa $21,75 \%$ anak perempuan di perkotaan menikah pada usia dibawah 16 tahun, dan $47,79 \%$ di kawasan pedesaan. Selain itu, hal ini dapat dilihat pada budaya masyarakat yang mempunyai kecenderungan untuk menikah pada usia dini karena adanya rasa malu bagi orang tua jika anak perempuannya yang sudah dianggap dewasa meskipun belum cukup umur tidak segera menikah.

Dibalik kontroversi terhadap pernikahan dini, data menunjukkan dampak negatif baik fisik maupun psikis bagi remaja yang melakukan pernikahan dini. Secara fisik, organ reproduksi remaja belum siap untuk melaksanakan salah satu tugas reproduksi yaitu hamil dan melahirkan. Berbagai komplikasi kehamilan dan persalinan lebih beresiko terjadi pada usia dini. Secara psikologis, remaja masih berada dalam tahap mencari jati diri, belum mampu untuk bertanggung jawab terhadap orang lain, apalagi menjadi orang tua. Hal ini meningkatkan resiko munculnya konflik-konflik dalam rumah tangga.

Dari sudut pandang kesehatan, perempuan yang melakukan hubungan seksual dibawah umur 20 tahun beresiko terkena kanker leher Rahim karena selsel leher rahim belum tumbuh dengan matang. Hubungan seksual yang dilakukan saat usia remaja meningkatkan resiko terpapar oleh Human Papiloma Virus (HPV), virus penyebab kanker serviks. Saat ini, kanker leher rahim menduduki peringkat pertama kanker yang menyerang perempuan Indonesia, angka kejadiannya saat ini 23\% diantara kanker lainnya (Purwaningsih,2014).

Pernikahan dini juga menghentikan kesempatan seorang remaja meraih pendidikan yang lebih tinggi, sehingga dia tidak memperoleh kesempatan pengetahuan dan wawasan yang lebih luas ditambah dengan sempitnya mendapatkan lapangan pekerjaan sehingga sulit untuk meningkatkan taraf kehidupan. Fenomena perkawinan dibawah umur menimbulkan kontroversi di masyarakat karena adanya sudut pandang yang berbeda.

Pergeseran budaya tampaknya sudah terjadi di Yogyakarta. Aturan tidak tertulis yang dahulu dianut dengan kuat saat ini tampak longgar. Saat ini masyarakat seolah menjadi terbiasa untuk melihat pasangan lawan jenis bergandengan tangan, berboncengan, bahkan bermesraan ditempat umum. Tidak jarang hal-hal tersebut dilakukan oleh anak-anak berseragam sekolah. Jika hal ini terjadi terus menerus maka akan mengarah pada pergaulan bebas dan hamil diluar nikah yang berlanjut pada pernikahan dini.

Dari uraian diatas maka tujuan umum penelitian ini adalah untuk mengetahui fenomena pergeseran budaya dengan trend pernikahan dini di Kecamatan Godean Kabupaten Sleman D.I. Yogyakarta.

\section{METODE PENELITIAN}

Metode penelitian dengan kualitatif dengan menggunakan wawancara mendalam (indepent interview). Pendekatan waktu crossectional. Penelitian ini dilakukan di KUA Kecamatan Godean Kabupaten Sleman D.I. Yogyakarta. Populasi dalam penelitian ini adalah seluruh pasangan usia subur yang ada di Kecamatan Godean Kabupaten Sleman D.I. Yogyakarta yang menikah dini usia kurang dari 16 tahun bagi perempuan atau 19 tahun bagi laki-laki. Teknik 
pengambilan sampel dengan purposive sampling. Subyek dalam penelitian ini meliputi: Tenaga kesehatan 1, Petugas KUA 1, Tokoh Masyrakat 1, Orangtua yang memiliki anak menikah dini 5, dan pasangan yang menikah dini 5 .

Instrumen dan teknik pengumpulan data dengan observasi yang dilakukan terhadap budaya yang berkembang dan mengalami pergeseran di wilayah tersebut, wawancara, dan dokumentasi.

Uji kredibilitas dilakukan dengan triangulasi, diskusi dengan teman sejawat dan analisis kasus.Teknik analisis data dengan cara data reduction (reduksidata), data display (penyajiandata), conclusion drawing/verification (penarikan kesimpulan).

\section{HASIL DAN PEMBAHASAN}

Kecamatan Godean merupakan wilayah dengan kepadatan penduduk yang tinggi sehingga calon pengantin yang akan melakukan pernikahanKecamatan Godean pun digolongkan tinggi. Di tahun 2016 sebanyak 383 calon penganten mendaftarkan diri di KUA Kec. Godean dan sebanyak 8 pasangan pengantin yang menikah dini yaitu bagi laki-laki kurang dari 19 tahun dan perempuan kurang dari 16 tahun sedangkan ditahun 2017 sebanyak 6 pasang yang melakukan pernikahan dini.

Pernikahan dini merupakan permasalahan sosial yang bertahun-tahun menjadi permasalahan yang terus dicari penyelesaiannya baik dari sisi pencegahan maupun penyelesaian akibat yang ditimbulkan dari pernikahan dini.Hasil penelitian ini menunjukkan bahwa semua informan pasangan muda melakukan pernikahan dini dikarenakan telah terjadi kehamilan sebelumnya. Berikut penuturan responden:

“...menikahan dini karena hamil diluar nikah..."

Artinya, hubungan seksual telah dilakukan oleh pasangan selama masa pacaran. Selanjutnya, pandangan sosial bahwa kehamilan hingga persalinan tanpa adanya pasangan merupakan hal yang memalukan dimasyarakat sehingga memaksa pasangan laki-laki beserta orang tua untuk segera melangsungkan pernikahan.

Berdasarkan hasil penelitian bahwa semua responden berusia $<19$ tahun. Hal ini sesuai dengan penelitian (Suparman, 2011) alasan anak menikah muda yaitu seks bebas dan akhirnya hamil di luar nikah, dan satu- satunya alternative yang dapat mereka pilih adalah menikahkan anak-anak mereka walaupun masih di bawah umur. Dalam penelitian ini alasan menikah dini karena hamil diluar nikah.

Kurangnya peran orang tua dalam mendampingi tumbuh kembang anak memasuki masa remaja dianggap sebagai salah satu faktor penyebab terjadinya pernikahan dini. Banyaknya waktu orang tua yang digunakan untuk pekerjaan ditambah dengan berkurangnya pendampingan agama membuat remaja tumbuh tanpa bekal yang kuat menghadapi perubahan fisik dan psikis di usia remaja. Berikut penuturan responden pegawai KUA bahwa saat ini orangtua kurang memperhatikan anaknya: 
“...faktor penyebabnya adalah orangtua yang kurang memperhatikan anaknya, ada teman laki-lakinya datang orangtua justru pergi dan meninggalkan berduan dirumah..."

"...Selain itu banyaknya kasus pernikahan dini karena faktor agama yang kurang karena agama tidak dijalankan dengan baik, tidak pernah solat..."

Secara garis besar, beberapa faktor penyebab pernikahan dini yang diperoleh pada penelitian ini adalah karena kurangnya pendampingan orang tua, kurangnya pendidikan tentang agama, adanya pergeseran norma sosial terhadap kehamilan diluar nikah.

Masyarakat saat ini mulai terbiasa dan menerima adanya pernikahan dini karena kehamilan diluar nikah. Hal ini menunjukkan adanya pergeseran norma sosial di masyarakat Indonesia khususnya Propinsi Daerah Istimewa Yogyakarta. Berikut penuturan responden mengenai hal tersebut:

“...adanya pergeseran norma budaya terutama banyaknya remaja yang melakukan hubungan seksual sebelum menikah. Terjadi pergeseran norma awalnya merupakan hal yang memalukan dan menjadi aib namun saat ini sudah menjadi hal biasa saja..."

Ketika mengetahui anaknya hamil diluar nikah maka respon orang tua saat itu kaget, namun kemudian bisa menerima kenyataan dan memberikan dukungan untuk segera menikah. Berikut penuturan responden:

“...saat tahu jika anak saya hamil diluar nikah kaget tapi mau bagaimana lagi akhirnya menikah..."

Hal ini membuktikan adanya pergeseran norma dalam masyarakat Indonesia khususnya Yogyakarta yang mulai terbiasa menerima kasus pernikahan dini dengan latar belakang kehamilan yang tidak diinginkan.Hal ini tidak sejalan dengan rekomendasi WHO yang justru mendorong untuk terbentuknya komunitas masyarakat yang tidak memberikan toleransi terhadap seksual diluar nikah. Bahkan, aktivitas sosial diluar nikah dianggap sebagai salah satu contoh kekerasan seksual pada anak dan remaja (Chandra-Mouli, et.al, 2013).

Responden dalam penelitian ini adalah pasangan usia subur yang mayoritas berpendidikan SD, SMP dan SMA.Dalam penelitian ini di dapatkan satu responden berpendidikan SMA. Dari hasil wawancara di dapatkan bahwa responden yang berpendidikan SMA mampu merespon kehidupan rumah tangganya lebih baik dibandingkan dengan yang pendidikan SD dan SMP misalnya dalam hal adaptasi dalam peran rumah tangga, kestabilan emosi sehingga jarang bertengkar dengan suami, dll.

Hal ini sejalan dengan penelitian Wisnuwardhani dan Sri (2012) bahwa seseorang yang memiliki latar belakang pendidikan yang baik mampu dalam merespon, berkomunikasi dan beradaptasi dengan orang lain. Persiapan pribadi meliputi kematangan emosi, kesiapan usia, kematangan sosial dan persiapan model peran.

Menikah di usia dini membawa banyak konsekuensi kesehatan, pendidikan, ekonomi dan social (BKKBN, 2014). Hal ini sejalan dengan hasil dalam penelitian ini bahwa konsekuensi yang harus ditanggung oleh pasangan yang menikah muda salah atunya adalah rendahnya kesempatan khususnya bagi perempuan untuk melanjutkan pendidikan, sedangkan pendidikan terakhir 
mayoritas responden adalah SD dan SMP. Rendahnya tingkat pendidikan responden ini berpengaruh pada sulitnya kesempatan mendapatkan pekerjaan dan penghasilan yang layak sehingga menimbulkan masalah ekonomi tersendiri bagi responden. Masalah ekonomi ini menjadi salah satu pemicu ketidakharmonisan rumah tangga. Berikut penuturan responden:

“...karena saya lulusan SD sehingga mau mencari pekerjaan sulit..."

Secara psikologis, remaja perempuan yang hamil diluar nikah kemudian menikah dan tidak dapat melanjutkan sekolah menimbulkan kecemasan tersendiri. Secara sosial, pernikahan dini dapat menghambat upaya pengembangan diri khususnya pada perempuan karena hilangnya kesempatan untuk bersekolah lagi. Hilangnya kesempatan pada remaja untuk melanjutkan pendidikan berhubungan dengan kesempatan memperoleh pekerjaan. Sebuah penelitian yang dilakukan di India menunjukkan bahwa remaja yang tidak menempuh pendidikan pada tingkat menengah yaitu pada usia sebelum 18 tahun cenderung lebih rentan untuk melakukan pernikahan dini $(7,77(5,29-11,40)$. Selanjutnya, intervensi dalam bentuk peer group education efektif menurunkan kecenderungan menikah dini namun hanya pada remaja perempuan, tidak pada remaja laki-laki (OR 2,71, CI $1,61-4,75)$. Terlebih lagi, kurangnya akses terhadap media informasi tentang reproduksi meningkatkan resiko terhadap pernikahan dini.

Informasi dari salah satu pasangan yang menjalani pernikahan dini juga menyebutkan bahwa ada perasaan kaget karena belum terbayang sebelumnya bahwa akan menikah dan menjadi seorang ibu dalam waktu yang sangat cepat. Kondisi tersebut menggambarkan bahwa belum adanya kesiapan secara psikis dan psikologis dalam menjalankan peran sebagai seorang istri sekaligus sebagai seorang ibu.Namun dengan kondisi seorang perempuan siap tidak siap harus menjalankan perannya.

Menurut penelitian mubasyaroh (2016) untuk membentuk suatu keluarga harus dipersiapkan dengan matang diantaranya pasangan yang akan membentuk keluarga harus sudah dewasa, baik

secara biologis maupun pedagogis atau bertanggung jawab. Bagi pria harus sudah siap untuk memikul tanggung jawab sebagai kepala keluarga, sehingga berkewajiban member nafkah kepada anggota keluarga. Bagi seorang wanita ia harus sudah siap menjadi ibu rumah tangga yang bertugas mengendalikan rumah tangga, melahirkan, mendidik, dan mengasuh anak-anak.

Untuk mengatasi ketidak siapan dalam berumah tangga dibutuhkan dukungan terhadap remaja dalam menghadapi perubahan sosial yang terjadi (Mehra, 2018).Meskipun demikian, semua informan menyampaikan bahwa hubungan mereka dengan lingkungan sosial mereka baik-baik saja karena sosial dianggap sudah dapat menerima kondisi yang terjadi. Rasa malu yang muncul pada awal kehamilan mulai memudar setelah pernikahan berlangsung. Penerimaan dan dukungan dari orang tua pun memperkuat pasangan pernikahan dini dalam memenuhi kebutuhan hidup berumah tangga.

Dalam penelitian Sari (2013) dengan judul "Kesiapan Menikah Pada Dewasa Muda Dan Pengaruhnya Terhadap Usia Menikah" dalam penelitian ini membahas faktor yang dianggap penting salah satunya adalah dukungan sosial baik dari pasangan, keluarga, teman maupun masyarakat dalam segala keputusan 
yang akan diambil. Sehingga kesiapan dukungan sosial sangatlah penting untuk kesiapan calon pengantin yang akan menikah. Dukungan social diberikan dalam bentuk kenyamanan, perhatian, penghargaan, maupun bantuan dalam bentuk yang lainnya yang diterima dari orang lain seperti teman-teman dan anggota keluarga.

Whitton et. al (2007) menyebutkan bahwa pasangan yang menikahdini menunjukkan kecenderungan mudah mengalami gejala depresi. Hal ini berkaitan dengan kesiapan dan kemampuan dalam menghadapi konflik yang terjadi selama berumah tangga. Sebagian besar dari pasangan tersebut tidak mampu bertahan dalam rumah tangganya setelah 1 tahun pernikahan. Dalam penelitian ini di dapatkan hasil beberapa responden mengatakan sering bertengkar dengan suami sehingga menggangu keharmonisan keluarga bahkan mengatakan untuk cerai. Pernikahan dini memiliki potensi lebih besar untuk mengalami kegagalan (cerai) karena ketidaksiapan sosial dan mental dalam menghadapi dinamika rumah tangga tanggung jawab atas peran masing-masing seperti dalam mengurus rumah tangga, mencukupi ekonomi dan mengasuh anak (BKKBN, 2014). Berikut penuturan responden:

“...kurang harmonis sering bilang ke suami untuk pisah dan cerai saja apalagi jika sedang ada masalah, biasanya masalahnya karena ekonomi. Setelah melahirkan karena terlalu stress..."

Dampak dari pernikahan dini bukan hanya dari dampak kesehatan, tetapi punya dampak juga terhadap kelangsungan perkawinan. Sebab perkawinan yang tidak direncanakan, mempunyai dampak tingginya perceraian (Ahmad, 2009). Berdasarkan hasil wawancara mendalam dengan responden mereka menyampaikan bahwa kadang terjadi pertengkaran dengan suami, ada yang menyampaikan pertengkaran yang wajar, bahkan ada yang menyampaikan seringnya durasi pertengkaran yang terjadi dalam satu minggu sehingga menggangu keharmonisan keluarga.

Hal ini sejalan dengan penelitian Sari (2013) usia ideal menikah bagi lakilaki yaitu 26- 28 tahun dan usia ideal menikah bagi perempuan yaitu 23- 25 tahun dikarenakan seseorang diusia tersebut sudah memiliki usia yang matang untuk menikah.Dalam penelitian ini responden yang menikah berusia kurang dari 19 tahun sehingga beberapa responden belum memiliki kematangan emosi, hal ini dibuktikan dengan pertengkaran yang terjadi dalam rumah tangga karena hal kecil dan masih besarnya peran dan pengaruh orangtua dalam kehidupan rumah tangga mereka, beberapa responden menyampaikan kadang mudah marah dan emosi kepada suami.

Menurut Caragih(2013) umur sangat mempengaruhi karakterisitik seorang. Usia yang lebih muda atau menikah muda mempunyai pengalaman, dan kematangan emosi yang berbeda dengan orang yang cukup umur. Pada usia muda mungkin adanya perbedaan pengalaman dan kurangnya informasi karena dampak dari perbedaan umur akan berpengaruh pada kesiapan menikah.

Pernikahan dini membuat responden mengalami kesulitan dalam beradaptasi dalam menjalani perannya yang baru misalnya peran sebagai istri, sebagai ibu, sebagai bapak dan sebagai pencari nafkah dalam keluarga. Berikut penuturan responden: 
“...suami sudah berperan dengan baik, membantu mengurus anak, mau bekerja juga. Klo saya (istri) kurang berperan maksimal karena masak tidak bisa, kadang sering marah-marah dengan suami..."

Hal ini sejalan dengan penelitian Roumali (2012) pernikahan di usia remaja pada umumnya akan menimbulkan masalah baik fisiologis, psikologis dan sosial ekonomi. Kesulitan dalam beradaptasi tertutama dialami oleh remaja putri yang melangsungkan pernikahan dini. Hal ini sejalan dengan Santhya (2011) dampak pernikahan usia dini lebih dirasakan pada remaja putri di bandingkan remaja lakilaki misalnya terjadinya abortus atau keguguran karena secara fisiologis organ reproduksi (khususnya rahim) belum sempurna selain itu berpotensi mengalami kehamilan dengan komplikasi, persalinan prematur, bayi lahir dengan berat badan lahir rendah, kematian bayi, yang semakin meningkatnya jika kejadian kekerasan dalam rumah tangga.

Untuk mengurangi masalah pada pasangan yang menikah dini orangtua memberikan banyak bantuan dan dukungan. Responden menyampaikan bahwa orangtua selama ini banyak membantu dan memberikan dukungan baik moril maupun finansial. Sedangkan dalam penelitian ini didapatkan hasil bahwa kondisi ekonomi keluarga bagi pasangan yang melakukan pernikahan dini mayoritas berasal dari keluarga dengan ekonomi menengah kebawah dan semua responden saat ini tinggal dengan orangtua untuk mempermudah melakukan perannya yang baru. Hal ini membuat masalah tersendiri karena orangtua dengan kehidupan yang pas-pasan diperberat dengan kondisi anak yang belum mapan dari segi ekonomi sehingga menjadi beban ganda bagi perekonomian keluarga.

Berbagai program dan upaya telah dilakukan untuk menurunkan kasus pernikahan dini misalnya kerjasama lintas sektoral yang dilakukan dengan Puskesmas maupun program khusus dari KUA Kec Godean. Selama ini pihak KUA Kecamatan Godean merancang program dalam rangka mengatasi tingginya angka kejadian pernikahan dini di Kecamatan Godean baik dalam bentuk pembinaan bagi caten maupun yang lainnya. Berikut penuturan responden:

"...ada program khusus caten yaitu pembinaan pra nikah yang dilaksanakan 1 bulan sekali pada senin ke 2 namun memang tidak semuanya mengikuti pembinaan..."

Berbagai upaya dan usaha telah dilakukan oleh seluruh aparat pemerintahan Kec Godean namun saat ini kehamilan diluar nikah dan dan pernikahan dini masih tetap menjadi masalah utama dalam bidang Kesehatan Remaja di Kecamatan Godean.

\section{KESIMPULAN}

Faktor remaja melakukan pernikahan dini diKecamatan Godean karena kehamilan tidak diinginkan. Fenomena pernikahan dini karena kehamilan tidak diinginkan bukan menjadi hal yang tabu lagi di masyarakat meskipun itu adalah aib yang harus di tutupidan saat ini sudah menjadi fenomena biasa yang ada di masyarakat. 
Mayoritas informan yang menikah dini karena kehamilan tidak diinginkan kurang memiliki kesiapan fisik, sosial, psikologis dan spiritual. Dampak dari pernikahan dini karena kehamilan tidak diinginkan adalah mereka tidak dapat melanjutkan pendidikan karena mayoritas adalah lulusan SD dan SMP sehingga sulit mendapatkan pekerjaan yang menimbulkan masalah keuangan dalam rumah tangga. Dampak lain yang ditimbulkan dari pernikahan dini adalah kurangnya keharmonisan di dalam keluarga misalnya pertengkaran sampai dengan menginginkan perceraian.

Program KUA dan Puskesmasdalam menurunkan tingginya angka pernikahan dini di Kecamatan Godean dilakukan dengan program khusus bagi calon penganten yaitu pembinaan pra nikah, kajian yang dilakukan oleh tokoh masyarakat, penyuluh honorer, dan adanya kerjasama lintas sektoral dalam meningkatkan kesehatan reproduksi remaja.

\section{DAFTAR PUSTAKA}

Ahmad. (2009). Pencegahan Pernikahan Usia Dini (http//alfiyah23.student.umm.ac.id.) di akses tanggal 20 Maret 2017.

BKKBN. (2014). Kesiapan Kehamilan. Hindari Kawin Muda Agar Hidup Bahagia (http://www.BKKBN.co.id) di akses tanggal 20 Maret 2017.

Caragih. (2013). Karakteristik Sosial Secara Umum. https://www.trendilmu.com/2015/06/pengertian-karakteristik-secaraumum.html. diakses pada tanggal 01 Agustus 2017.

Chandra-Mouli, V., Camacho, A.V., Michaud, P. (2013). WHO Guidelines on Preventing Early Pregnancy and Poor Reproductive Outcomes Among Adolescents in Developing Countries. Journal of Adolescent Health. 52: 517-522.

Guilbert, N. (2013). Early Marriage, Women Empowerment And Child Mortality:Married Too Young To Be A Good Mother Psl, Université ParisDauphine, Leda, Umr Dial, 75016 Paris, France Ird, Umr Dial, 75010 Paris.

Mehra, D., Archana.S., Priyanka. S., Jagannath. B., Sunil. M. (2018). Effectiveness of A Community Based Intervention to Delay Early Marriage, Early Pregnancy and Improve School Retention among Adolescent in India. BMC Public Health 18:732.

Mubasyaroh (2016). Analisis Faktor Penyebab Pernikahan Dini dan Dampaknya Bagi Pelakunya. Skripsi. Diakses tanggal 24 maret 2017

Purnomo. (2013). Dampak Perkawinan Usia Dini terhadap Kondisi Sosial Ekonomi Keluarga. Thesis. Diakses tanggal 24 Maret 2017.

Purwaningsih, E., \& Setyaningsih, R. T. (2014). Hubungan Pola Asuh Orang Tua Dengan Kejadian Pernikahan Usia Dini Di Desa Jambu Kidul, Ceper, Klaten. Jurnal Involsi Kebidanan. 4. 1- 12. Januari 2014. http://ejournal. stikesmukla.ac.id/index.php/involusi/article/view/43diakses 25 Mei 2017.

Roumali. (2012). Dampak Pernikahan DiniDi Indonesia. Dalam https://journal.ugm.ac.id/jurnalpemuda/article/viewFile/32033/19357.

Diakses Tanggal 28 November 2017. 
Santhya,K.G. (2011). Early Marriage and Sexual and Reproductive Health Vulnerable Women: A Synthesis of Recent Evidence from Developing Countries. Current Opinion in Obstetrics Gynecology. 23(5):334-339. Retrieved from https://www.ncbi.nlm.nih.gov/pubmed/21836504.

Sari, F., dan Sunarti, E. (2013). Kesiapan Menikah pada Dewasa Muda dan Pengaruhnya Terhadap Usia Menikah. Jurnal Ilmu Keluarga dan Konsumen. Vol. 6, No. 3., P: 143-153. http://journal.ipb.ac.id/index.php/jikk/article/viewFile/9982/7804. Diakses pada tanggal 18 November 2017 pukul 21.00 WIB.

Suparman. (2011). Perbedaan Gender. Dalam https://www.google.co.id/search?q=Suparman.+(2011).+Perbedaan+Gend er\&oq=Suparman.$+(2011) .+$ Perbedaan + Gender\&aqs $=$ chrome..69i57.719j0 j7\&sourceid $=$ chrome\&ie $=$ UTF-8Diakses Tanggal 30 Maret 2018.

Undang Undang Perkawinan Nomor 1 Tahun 1974. Surabaya: Penerbit Karya Anda.

UNICEF Indonesia. (2016). Kemajuan yang Tertunda: Analisis Data Perkawinan Usia Anakdi Indonesia. Badan Pusat Statistik: Jakarta.

Wisnuwardhani, D., \& Sri F. M. (2012). Hubungan Interpersonal. Jakarta: Salemba Humanika.

Whitton SW, Olmos-Gallo PA, Stanley SM, Prado LM, Kline GH, St. Peters M, et al. Depressive symptoms in early marriage: Predictions from relationship confidence and negative marital interaction. Journal of Family Psychology. 2007;21:297-306. 